\title{
Concordant acute myeloblastic leukemia in identical twins treated with allogeneic transplantation from a younger HLA-identical sibling following a single apheresis procedure
}

\author{
Yajaira Valentine Jimenez-Antolinez ${ }^{1}$ (D) , Elias Eugenio Gonzalez-Lopez ${ }^{1}$ (D) Ileana Yazmín \\ Velasco-Ruiz'1, Marcela Cantu-Moreno ${ }^{1}$, David Gomez-Almaguer ${ }^{1}$ iD \& Oscar \\ Gonzalez-Llano*,1 \\ ${ }^{1}$ Hematology Service, Hospital Universitario 'Dr. Jose E. Gonzalez', Universidad Autónoma de Nuevo León, Monterrey, Nuevo León, \\ México \\ *Author for correspondence: ogzzII25@hotmail.com
}

\begin{abstract}
A concordant leukemia is that which occurs in a pair of monozygotic twins; a similar genetic background suggests an in utero monoclonal origin. We present the case of a pair of monozygotic infants with concordant acute myeloid leukemia who underwent a peripheral blood hematopoietic stem-cell transplant (HSCT) from a single, younger human leukocyte antigen-identical sibling donor, using a fractioned graft collected during only one apheresis procedure. Twin A relapsed at +456 and received a second haploidentical HSCT from his father, twin B has been in complete remission since the first HSCT. Both children are in complete remission and with negative minimal residual disease at +900 (after second transplant) and +1488 , respectively.
\end{abstract}

First draft submitted: 3 July 2020; Accepted for publication: 28 September 2020; Published online: 20 November 2020

Keywords: bone marrow transplantation • concordant leukemia • infant acute leukemia • matched sibling donor - measurable residual disease • myelodysplastic syndrome • peripheral blood stem cell • single apheresis • twins - younger donor

The first case report of concordant leukemia in twins appeared in the literature in 1882 and since then many such pairs of infants have been described [1,2]. By the year 2003 there had been 70 similar cases described [3]. Different molecular markers, including genomic fusion gene sequences, have provided evidence that cases of twins with leukemia have a common clonal origin [2]. The origin of infant acute myeloid leukemia (IAML) twins is an in utero acquired leukemic clone, which arises in one twin and is then metastasized to the other twin through the placenta. These in utero mutations involve in up to $80 \%$ of cases the $11 \mathrm{q} 23$ (KMT2A) gene [4].

Here we present the experience of a pair of twins with acute myeloblastic leukemia being transplanted using the same donor. Table 1 shows patients characteristics.

Twin A

A 17-month-old infant was referred due to a history of pallor, epistaxis and bone pain. He had a hemoglobin of $2.9 \mathrm{~g} / \mathrm{dl}$, a leukocyte count of $7.41 \times 10^{9} / \mathrm{l}$, an absolute neutrophil count (ANC) of $0.25 \times 10^{9} / 1$, a lymphocyte count of $5.9 \times 10^{9} / 1$ and platelets of $105 \times 10^{9} / \mathrm{l}$. The peripheral blood smear showed blasts with myeloid lineage characteristics, later confirmed by bone marrow flow cytometry with a blast population of $22 \%$ of the total mononuclear cells. The blasts were $\mathrm{CD} 33^{+}, \mathrm{CD}_{6} 4^{+}, \mathrm{CD} 56^{+}$, with characteristics of myelodysplasia due to an alteration in the pattern of expression of CD11b/CD13 and CD11b/CD16. Cytogenetic analysis showed a $\mathrm{t}(2 ; 11)$ and an isodicentric X chromosome. The patient received the MRC acute myeloid leukemia (AML) 10 protocol with

Future Medicine 


\section{Table 1. Patient characteristics.}

\begin{tabular}{|c|c|c|}
\hline Characteristics & Twin A & Twin B \\
\hline Sex & Male & Male \\
\hline Age at diagnosis (months) & 17 & 17 \\
\hline Leukocyte count at diagnosis $\times 10^{9} / \mathrm{l}$ & 7.41 & 5.77 \\
\hline Lymphocyte count at diagnosis $\times 10^{9} / \mathrm{I}$ & 5.9 & 4.94 \\
\hline Platelet count at diagnosis $\times 10^{9} / \mathrm{I}$ & 105 & 46 \\
\hline Hemoglobin count at diagnosis $(\mathrm{g} / \mathrm{dl})$ & 2.9 & 8.2 \\
\hline Percentage of blasts, bone marrow (\%) & 22 & 74 \\
\hline Blasts immunophenotype & $\begin{array}{l}\mathrm{CD}^{2} 3^{+}, \mathrm{CD} 4^{+}, \mathrm{CD} 6^{+}, \mathrm{CD} 117^{+}, \mathrm{MPOC}+ \\
\mathrm{CD} 11 \mathrm{~b} / \mathrm{CD} 13, \mathrm{CD} 11 \mathrm{~b} / \mathrm{CD} 16\end{array}$ & $\begin{array}{l}\text { HLA-DR }+, \mathrm{CD}_{13}^{+}, \mathrm{CD} 33^{+}, \mathrm{CD} 64^{+}, \mathrm{CD} 56^{+}, \mathrm{CD} 117^{+}, \\
\text {MPOC }+, \mathrm{CD} 11 \mathrm{~b} / \mathrm{CD} 13, \mathrm{CD} 11 \mathrm{~b} / \mathrm{CD} 16\end{array}$ \\
\hline Cytogenetics & $\begin{array}{l}t(2 ; 11)(p 21 ; q 23.3) \\
\operatorname{idic}(X)(q 13)\end{array}$ & $\begin{array}{l}t(2 ; 11)(p 21 ; q 23.3) \\
\operatorname{idic}(X)(q 13)\end{array}$ \\
\hline Treatment before HSCT & AML 10 & AML 10 \\
\hline Postinduction MRD (\%) & 1.3 & 1.3 \\
\hline Pretransplant MRD (\%) & 1.4 & 0 \\
\hline Interval between diagnosis and HSCT (months) & 9 & 9 \\
\hline Weight (kg) & 12 & 12 \\
\hline Age at transplant (months) & 26 & 26 \\
\hline Donor source & Related, HLA matched sibling, PBSC & Related, HLA matched sibling, PBSC \\
\hline Donor weight (kg) & 12 & 12 \\
\hline $\mathrm{D} / \mathrm{R}$ blood group & $\mathrm{A} 1 / \mathrm{A}$ & $\mathrm{A} 1 / \mathrm{A}$ \\
\hline D/R CMV sero status & Negative/positive & Negative/positive \\
\hline $\mathrm{CD} 4^{+}$cells infused $\times 10^{6} / \mathrm{kg}$ & 6.4 & 6.4 \\
\hline Neutrophil engraftment (days) & +25 & +18 \\
\hline Platelet engraftment & Never below $20 \times 10^{9} / 1$ & Never below $20 \times 10^{9} / \mathrm{I}$ \\
\hline Acute GVHD & No & No \\
\hline Chronic GVHD & No & No \\
\hline Chimerism day $30(\%)$ & 90 & 92 \\
\hline
\end{tabular}

a postinduction minimal residual disease (MRD) of 1.3\% and an MRD of $1.4 \%$ before hematopoietic stem-cell transplant (HSCT).

An HLA-identical peripheral blood HSCT was performed with his 12-month-old sister, the conditioning regimen consisted of Cy $350 \mathrm{mg} / \mathrm{m}^{2} / \mathrm{d}$ and Flu $25 \mathrm{mg} / \mathrm{m}^{2} / \mathrm{d}$ from days -7 to -5 and busulfan $3.2 \mathrm{mg} / \mathrm{kg} / \mathrm{d}$ from days -4 to -2 . Graft-versus-host disease (GVHD) prophylaxis was cyclosporine A at $6 \mathrm{mg} / \mathrm{kg} / \mathrm{d}$ starting at day -1 and methotrexate $5 \mathrm{mg} / \mathrm{m}^{2} / \mathrm{d}$ on days $+1,+3$ and +5 . The donor was mobilized with granulocyte-colony stimulating factor at $10 \mathrm{mg} / \mathrm{kg} / \mathrm{d}$ for 4 days and after a single apheresis a total of $12.8 \times 10^{6} / \mathrm{kg}$ CD34 ${ }^{+}$were harvested. The graft was divided in two equal fractions, one was infused immediately to the patient and the other was cryopreserved.

Neutrophil engraftment was on day +25 and platelets were never below $20 \times 10^{9} / 1$. On days +30 and +100 chimerisms were at 90 and 96\%, respectively. The patient did not present GVHD at any time. At day +463 the patient relapsed, with $66 \%$ of myeloid blasts with the same immunophenotype as at diagnosis.

The patient received 5+2 (Cytarabine + mitoxantrone), achieving negative MRD, and was followed by a second $5+2$ regimen as consolidation. A haploidentical HSCT was performed, with his father as the donor. Conditioning regimen was the same as the first transplant, but GVHD prophylaxis was Cy $50 \mathrm{mg} / \mathrm{kg} / \mathrm{d}$ on days +3 and +4 , followed by cyclosporine A $6 \mathrm{mg} / \mathrm{kg} / \mathrm{d}$ and mycophenolate mofetil $30 \mathrm{mg} / \mathrm{kg} / \mathrm{d}$ starting at day +5 . Currently this boy is in complete remission with negative MRD at +900 days, and without GVHD.

\section{Twin B}

The monozygotic twin of the previous patient was asymptomatic and was evaluated 7 days after the diagnosis of his brother. A complete blood count showed a hemoglobin of $8.2 \mathrm{~g} / \mathrm{dl}$, leukocytes of $5.77 \times 10^{9} / 1$, an ANC of 
$0.13 \times 10^{9} / 1$, a lymphocyte count of $4.44 \times 10^{9} / 1$ and platelets of $46 \times 10^{9} / 1$. A bone marrow aspirate was performed and a population of blasts comprising $74 \%$ of nucleated cells with the same immunophenotype and cytogenetic alterations of his twin was observed. The patient received the same chemotherapy regimen of his twin, having a postinduction MRD of $1.2 \%$, but a negative pretransplant MRD. The patient received the cryopreserved fraction of the graft harvested from their sister 10 days after his brother. The same conditioning regimen and GVHD prophylaxis were used.

Neutrophil engraftment was on day +18 and platelets were never below $20 \times 10^{9} / 1$. On days +30 and +100 chimerism were 92 and $84 \%$, respectively. The patient has not presented GVHD since the transplant. His last evaluation was performed on +1488 and is still in remission.

\section{Discussion}

AML represents $20 \%$ of childhood leukemia, and has a higher incidence in infants with characteristic cytogenetic abnormalities [5]. IAML has a higher prevalence of unfavorable risk factors and an increased susceptibility to therapy-related toxicity [6].

In the above cases, the decision to perform an HSCT in CR1 was justified because the patients had high-risk leukemias [7,8]. Both patients had a $\mathrm{t}(2 ; 11)$ and an $\operatorname{idic}(\mathrm{X})$ - which are poor-outcome cytogenetics [9] - and had a postinduction MRD above $1 \%$, which is also considered as an independent negative prognostic factor [10,11].

The use of bone marrow as a source if the donor is smaller than the recipient can be difficult because 10 to $15 \mathrm{ml} / \mathrm{kg}$ of the recipient's weight is required to obtain an adequate number of stem cells. However, pediatric peripheral blood stem-cell donors can represent a significant challenge because of catheter placement and low blood volumes.

By the time the twins' donor was harvested, our group had already published our experience with 27 PBSC collections performed on 22 children weighing $20 \mathrm{~kg}$ or less. One apheresis procedure was enough to obtain at least $2 \times 10^{6} \mathrm{CD} 34^{+}$cells per $\mathrm{kg}$ of recipient bodyweight in $78.5 \%$ of donors and the median number of CD34 $4^{+}$ collected was $5.79 \times 10^{6}$ per $\mathrm{kg}$ [12].

There is only one other case report where a fractionated graft from a single procedure was used as a stem-cell source in twins with IAML [13]. The similarities with our case report are that an HLA-matched sibling was the donor and that one graft fraction was cryopreserved. The main differences with our report are that the donor of our patients was younger and smaller than the recipients and that the source of stem cells was peripheral blood. The conditioning regimens were different; we used a combination of fludarabine, cyclophosphamide and busulfan IV, which we have shown in a previous study to be effective for the achievement of engraftment in $92 \%$ of the cases [14].

Our patients were the same age at the time of diagnosis, received the same induction and consolidation protocols and had a simultaneous HSCT with the same donor and conditioning regimens; however, only one of them relapsed. The only significant difference that we believe explains this is that the twin that relapsed had a positive MRD at the time of transplant, which has been shown in multiple studies to be an independent adverse prognostic factor $[10,11]$. However, the difference in MRD can reflect underlying differences in identical twins. Several studies have shown identical twins can have differences in epigenetic variation, somatic genetic variants, including copy number variants and mitochondrial changes, resulting from unequal distribution of molecular factors [15-17].

We decided not to use the same donor for the second transplant of twin A, because the presence of a mismatched haplotype in the new allograft in comparison with the first transplant has shown to improve survival [18].

This case report exemplifies that a pediatric donor can be used safely to obtain more than one graft in a single apheresis procedure, even for recipients that have higher weight; it also demonstrates that even patients with the exact same genetics, disease origin and environment, can have a different evolution and that pre-transplant MRD as a prognostic factor still applies in such cases.

\section{Future perspective}

Since achievement of negative MRD is an important pretransplant prognostic factor, reaching this goal is essential for all leukemic patients; currently the combination of venetoclax and azacitidine has proven to be effective for achieving complete remission in elderly patients with AML, accomplishing sustained remissions and responses even in chemotherapy refractory disease. There are a few uplifting reports of pediatric cases with AML treated with this drug combination. If proven to be safe in children, this targeted therapy could offer the means to obtain negative pretransplant MRD in patients that do not reach this threshold with conventional chemotherapy. 


\section{Summary Points}

- Infant acute myeloid leukemia (IAML) is characterized by a high rate of genetic abnormalities, next generation sequencing, if available or cytogenetics with a molecular abnormalities panel should always be performed.

- A total of $10 \%$ of IAML cases are myelodysplastic syndrome related.

- All monozygotic twins of an IAML patient should have a clinical evaluation and a complete blood count assessed by a pediatric hematologist, as soon as possible after diagnosis.

- Postinduction positive minimal residual disease by flow cytometry is an independent risk factor for relapse and mortality in pediatric acute myeloid leukemia.

- Pretransplant minimal residual disease in IAML is an independent prognostic factor for event-free and overall survival.

- Peripheral blood stem cell harvest in donors weighing under $20 \mathrm{~kg}$ is safe and effective.

Financial \& competing interests disclosure

The authors have no relevant affiliations or financial involvement with any organization or entity with a financial interest in or financial conflict with the subject matter or materials discussed in the manuscript. This includes employment, consultancies, honoraria, stock ownership or options, expert testimony, grants or patents received or pending, or royalties.

No writing assistance was utilized in the production of this manuscript.

Informed consent disclosure

The authors state that they have obtained verbal and written informed consent from the patient's legal guardian for the inclusion of their medical and treatment history within this case report.

Open access

This work is licensed under the Attribution-NonCommercial-NoDerivatives 4.0 Unported License. To view a copy of this license, visit http://creativecommons.org/licenses/by-nc-nd/4.0/

\section{References}

Papers of special note have been highlighted as: $\bullet \bullet$ of considerable interest

1. Senator H. Zur Kenntniss der Leukämie und Pseudoleukämie im Kindesalter. Berliner Klin. Wochenschrift 19(35), 533-536 (1882).

2. Greaves MF, Maia AT, Wiemels JL, Ford AM, Dc W. Leukemia in twins: lessons in natural history Review article Leukemia in twins: lessons in natural history. Blood 102(7), 2321-2333 (2013).

-• A complete and comprehensive review of leukemia in twins, with past and current theories on etiology and disease development.

3. MacMahon B, Levy MA. Prenatal origin of childhood leukemia. evidence from twins. N. Engl. J. Med. 270, 1082-1085 (1964).

4. Ford AM, Ridge SA, Cabrera ME et al. In utero rearrangements in the trithorax-related oncogene in infant leukaemias. Nature 363(6427), 358-360 (1993).

5. Pombo-de-Oliveira MS, Gomes Andrade F, Abdallah $\mathrm{H}$ et al. Acute myeloid leukaemia at an early age: reviewing the interaction. Ecancermedicalscience 11, 1-13 (2017).

6. Masetti R, Rondelli R, Fagioli F et al. Infants with acute myeloid leukemia treated according to the Associazione Italiana di Ematologia e Oncologia Pediatrica 2002/01 protocol have an outcome comparable to that of older children. Haematologica 99(8), e127-129 (2014).

7. Leung W, Campana D, Yang J et al. High success rate of hematopoietic cell transplantation regardless of donor source in children with very high-risk leukemia. Blood 118(2), 223-230 (2011).

8. Woolfrey AE, Gooley TA, Sievers EL et al. Bone marrow transplantation for children less than 2 years of age with acute myelogenous leukemia or myelodysplastic syndrome. Blood 92(10), 3546-3556 (1998).

9. Arber DA, Orazi A, Hasserjian R et al. The 2016 revision to the World Health Organization classification of myeloid neoplasms and acute leukemia. Blood 127(20), 2391-2405 (2016).

10. Buldini B, Rizzati F, Masetti R et al. Prognostic significance of flow-cytometry evaluation of minimal residual disease in children with acute myeloid leukaemia treated according to the AIEOP-AML 2002/01 study protocol. Br. J. Haematol. 177(1), 116-126 (2017).

11. Rubnitz JE, Inaba H, Dahl G et al. Minimal residual disease-directed therapy for childhood acute myeloid leukemia: results of the AML02 multicenter trial. Lancet Oncol. 11(6), 543-552 (2010).

12. Salazar-Riojas R, García-Lozano JA, Valdés-Galván M et al. Effective collection of peripheral blood stem cells in children weighing 20 kilogram or less in a single large-volume apheresis procedure. J. Clin. Apher. 30(5), 281-287 (2015).

-. This article includes the complete technical review of the apheresis procedure in children weighing less than $20 \mathrm{~kg}$. 
13. Shinkoda $\mathrm{Y}$, Ijichi $\mathrm{O}$, Tanabe $\mathrm{T}$ et al. Identical reconstitution after bone marrow transplantation in twins who received fresh and cryopreserved grafts harvested at the same time from their older brother. Clin. Transplant. 18(6), 743-747 (2004).

14. González-Llano O, González-López EE, Ramírez-Cázares AC, Marcos-Ramírez ER, Ruiz-Argüelles GJ, Gómez-Almaguer D. Haploidentical peripheral blood stem cell transplantation with posttransplant cyclophosphamide in children and adolescents with hematological malignancies. Pediatr. Blood Cancer 63(11), 2033-2037 (2016).

15. Bruder CEG, Piotrowski A, Gijsbers AACJ et al. Phenotypically concordant and discordant monozygotic twins display different DNA copy-number-variation profiles. Am. J. Hum. Genet. 82(3), 763-771 (2008).

16. Bell JT, Spector TD. DNA methylation studies using twins: what are they telling us? Genome Biol. 13(10), 172 (2012).

17. Bouhlal Y, Martinez S, Gong H, Dumas K, Shieh JTC. Twin mitochondrial sequence analysis. Mol. Genet. Genomic Med. 1(3), 174-186 (2013).

18. Imus $\mathrm{PH}, \mathrm{Blackford} \mathrm{AL}$, Bettinotti $\mathrm{M}$ et al. Major histocompatibility mismatch and donor choice for second allogeneic bone marrow transplantation. Biol. Blood Marrow Transplant. 23(11), 1887-1894 (2017). 